\title{
PENGARUH TERAPI BERMAIN PLASTISIN (PLAYDOUGHT) TERHADAP KECEMASAN ANAK USIA PRASEKOLAH (3-6 TAHUN) YANG MENGALAMI HOSPITALISASI DI RUANG PERAWATAN ANAK RSUD BANGKINANG TAHUN 2017
}

\author{
ALINI \\ Dosen Prodi Sarjana Keperawatan FIK Universitas Pahlawan Tuanku Tambusai \\ Alini_09@yahoo.com
}

\begin{abstract}
ABSTRAK
Kecemasan merupakan kondisi emosional yang tidak menyenangkan yang ditandai oleh perasaan-perasaan subjektif atau perasaan yang tidak diketahui jelas sebabnya atau sumbernya seperti ketegangan, ketakutan, dan kekhawatiran. Berdasarkan data Survei Kesehatan Nasional (SUSENAS) tahun 2014 jumlah anak usia prasekolah di Indonesia sebesar 20,72\% dari jumlah total penduduk Indonesia. Berdasarkan data tersebut diperkirakan 35 per 100 anak menjalani hospitalisasi dan $45 \%$ diantaranya mengalami kecemasan. Kecemasan merupakan rasa khawatir dan takut yang tidak jelas sebabnya. Salah satu intervensi keperawatan anak untuk membantu mengurangi kecemasan anak prasekolah selama menjalani hospitalisasi adalah terapi bermain seperti plastisin (playdought). Penelitian ini bertujuan untuk mengetahui pengaruh terapi bermain plastisin (playdought) terhadap perubahan kecemasan anak usia prasekolah (3-6 tahun) yang mengalami hospitalisasi di ruang perawatan anak RSUD Bangkinang tahun 2017. Penelitian ini bersifat quasi eksperimental dengan rancangan Non-equivalent pretest-posttest. Pengambilan sampel sebanyak 15 orang anak usia prasekolah sebagai kelompok eksperimen dengan menggunakan teknik purposive sampling. Kecemasan anak diukur menggunakan Taylor Manifest Anxiety Scale (TMAS). Pengambilan data dilakukan dengan cara mengukur kecemasan sebelum dan setelah diberikan intervensi berupa terapi bermain plastisin (playdought). Hasil analisis statistik menggunakan uji $T$ dependent didapatkan nilai $p$-value $0,00<\alpha 0,05$ yang berarti terdapat pengaruh terapi bermain plastisin (playdought) terhadap perubahan kecemasan anak usia prasekolah (3-6 tahun) yang mengalami hospitalisasi di ruang perawatan anak RSUD Bangkinang tahun 2017. Diharapkan bagi tenaga kesehatan khususnya perawat di ruangan anak RSUD Bangkinang agar dapat memberikan terapi bermain plastisin (playdought) sebagai salah satu terapi bermain yang bisa dilakukan untuk mengurangi kecemasan pada anak usia prasekolah (3-6 Tahun) yang mengalami hospitalisasi.
\end{abstract}

Daftar Bacaan : 28 (2005-2016)

Kata Kunci : Anak Prasekolah, Hospitalisasi, Kecemasan, Terapi Bermain, Plastisin (Playdought) 


\section{PENDAHULUAN \\ Latar Belakang}

Kecemasan atau ansietas merupakan respon individu terhadap suatu keadaan yang tidak menyenangkan dan dialami oleh semua makhluk hidup dalam kehidupan sehari-hari. Anak usia prasekolah biasanya mengalami separation anxiety atau kecemasan perpisahan karena anak harus berpisah dengan lingkungan yang dirasakannya aman, nyaman, penuh kasih sayang, dan menyenangkan seperti lingkungan rumah, permainan, dan teman sepermainannya (Ardiningsih, 2006, dalam Dayani, 2015). Menurut Supartini (2004) dalam Sari (2016), kecemasan merupakan dampak dari hospitalisasi yang dialami oleh anak karena menghadapi stressor yang ada di lingkungan rumah sakit.

Kecemasan terbesar pada anak usia prasekolah selama menjalani hospitalisasi adalah kecemasan terjadinya perlukaan pada bagian tubuhnya. Semua prosedur atau tindakan keperawatan baik yang menimbulkan nyeri maupun tidak dapat menyebabkan kecemasan anak prasekolah. Hal ini disebabkan karena keterbatasan pemahaman anak mengenai tubuh (Alfiyanti, 2007, dalam Dayani, 2015).

Menurut Supartini (2004) adapun reaksi anak usia prasekolah yang menunjukkan kecemasan seperti anak menolak makan, menangis, sering bertanya tentang keadaan dirinya, mengalami sulit tidur, tidak kooperatif terhadap petugas kesehatan saat dilakukan tindakan keperawatan.

Permasalahan anak sakit merupakan permasalahan yang kompleks di Indonesia. Indonesia merupakan negara dengan angka kematian anak 27 per 1000 kelahiran hidup (UNICEF, 2015). Pada masa usia prasekolah aktifitas anak yang meningkat menyebabkan anak sering kelelahan sehingga menyebabkan rentan terserang penyakit akibat daya tahan tubuh yang lemah pula hingga anak diharuskan untuk menjalani hospitalisasi. Hasil survei UNICEF tahun 2012 menunjukkan prevalensi anak yang menjalani perawatan di rumah sakit sekitar $84 \%$.

Berdasarkan data Survei Kesehatan Nasional (SUSENAS) tahun 2014 jumlah anak usia prasekolah di Indonesia sebesar
$20,72 \%$ dari jumlah total penduduk Indonesia, berdasarkan data tersebut diperkirakan 35 per 100 anak menjalani hospitalisasi dan $45 \%$ diantaranya mengalami kecemasan.

Hospitalisasi merupakan pengalaman penuh stress bagi anak dan juga keluarganya (Nursalam, 2005). Hospitalisasi adalah suatu keadaan yang menyebabkan seorang anak harus tinggal di rumah sakit untuk menjadi pasien dan menjalani berbagai perawatan seperti pemeriksaan kesehatan, prosedur operasi, pembedahan, dan pemasangan infus sampai anak pulang kembali ke rumah (Supartini, 2004). Hospitalisasi pada anak merupakan proses yang dikarenakan suatu alasan yang berencana ataupun darurat, sehingga mengharuskan anak untuk tinggal di rumah sakit menjalani terapi dan perawatan sampai pemulangan kembali kerumah. Pada saat proses inilah terkadang anak mengalamai berbagai pengalaman yang sangat traumatis dan penuh dengan stres.

Berbagai reaksi anak terhadap hospitalisasi, yaitu menolak untuk bekerja sama sebagai mekanisme pertahanan reaksi perpisahan. Anak juga menganggap hospitalisasi sebagai hukuman dan perpisahan dengan orang tua sebagai bentuk kehilangan kasih sayang (Muscary, 2005).

Reaksi anak terhadap sakit berbeda-beda sesuai tingkat perkembangan anak (Supartini, 2004). Menurut Sacharin (1996), semakin muda anak semakin sukar baginya untuk menyesuaikan diri dengan pengalaman dirawat di rumah sakit. Selain itu, pengalaman anak sebelumnya terhadap proses sakit dan dirawat juga sangat berpengaruh. Apabila anak pernah mengalami pengalaman tidak menyenangkan dirawat di rumah sakit sebelumnya akan menyebabkan anak takut dan trauma. Sebaliknya apabila anak dirawat di rumah sakit mendapatkan perawatan yang baik dan menyenangkan anak akan lebih kooperatif pada perawat dan dokter (Supartini, 2004). Respon anak terhadap hospitalisasi dipengaruhi oleh tahapan usia perkembangan, pengalaman sebelumnya terhadap sakit, mekanisme pertahanan diri yang dimiliki, dan sistem dukungan yang tersedia. 
Perawatan anak dirumah sakit merupakan pengalaman yang penuh dengan stress, baik bagi anak maupun orang tua, lingkungan rumah sakit itu sendiri merupakan penyebab stress dan kecemasan pada anak. Pada anak yang dirawat di rumah sakit akan muncul tantangan-tantangan yang harus dihadapinya seperti mengatasi suatu perpisahan, penyesuaian dengan lingkungan yang asing baginya, penyesuaian dengan banyak orang yang mengurusinya, dan kerap kali harus berhubungan dan bergaul dengan anak yang sakit serta pengalaman mengikuti terapi yang menyakitkan (Supartini, 2004 dalam Liswaryana, 2016).

Permasalahan yang muncul terkait respon anak terhadap terhadap hospitalisasi adalah banyak anak menolak saat menjalani perawatan dirumah sakit karena harus menyesuaikan diri dengan lingkungan rumah sakit yang asing, apalagi menjalani rawat inap dalam jangka waktu yang lama. Tindakan perawatan yang diberikan dapat menimbulkan masalah psikologi baik bersifat emosional, kognitif, maupun sosial pada anak. Peralatan medis yang terlihat bersih dan prosedur medis dianggap anak menyakitkan dan membahayakan karena dapat melukai bagian tubuhnya. Hal inilah yang dapat menimbulkan terjadinya kecemasan pada anak (Rahmawati, 2008, dalam Liswaryana, 2016).

Dampak dari kecemasan pada anak yang menjalani perawatan, apabila tidak segera ditangani akan membuat anak melakukan penolakan terhadap tindakan perawatan dan pengobatan yang diberikan sehingga akan berpengaruh terhadap lamanya hari rawat anak dan dapat memperberat kondisi penyakit yang diderita anak. Untuk mengurangi dampak akibat hospitalisasi yang dialami anak selama menjalani perawatan, diperlukan suatu media yang dapat mengungkapkan rasa cemasnya, salah satunya adalah terapi bermain (Sujatmiko, 2013, dalam Dayani, 2015).

Bermain merupakan suatu aktivitas dimana anak dapat melakukan atau mempratikkan keterampilan, memberikan ekspresi terhadap pemikiran, menjadi kreatif, mempersiapkan diri untuk berperan dan berperilaku dewasa
(Hidayat, 2005). Menurut Sudono (2006) bermain adalah suatu kegiatan yang dilakukan dengan atau tanpa mempergunakan alat yang menghasilkan pengertian dan memberikan informasi, memberi kesenangan maupun mengembangkan imajinasi anak.

Terapi bermain adalah suatu kegiatan bermain yang dilakukan untuk membantu dalam proses penyembuhan anak dan sarana dalam melanjutkan pertumbuhan dan perkembangan anak secara optimal. Tujuan bermain bagi anak adalah menghilangkan rasa nyeri ataupun sakit yang dirasakannya dengan cara mengalihkan perhatian anak pada permainan sehingga anak akan lupa terhadap perasaan cemas maupun takut yang dialami, selama anak menjalani perawatan dirumah sakit. Permainan akan membuat anak terlepas dari ketegangan dan stres yang dialaminya karena dengan melakukan permainan, anak akan dapat mengalihkan rasa sakitnya pada permainannya dan relaksasi melalui kesenangannya melakukan permainan. Dengan terapi bermain, diharapkan kecemasan anak segera menurun, sehingga dapat menjadikan anak lebih bekerjasama pada petugas kesehatan.

Terapi bermain yang diberikan pada anak usia prasekolah harus menyesuaikan dengan tahapan perkembangan sesuai usianya. Pada masa prasekolah jenis permainan salah satunya adalah skill play, dimana jenis permainan ini sering dipilih oleh anak, jenis permainan ini menggunakan kemampuan motoriknya. Salah satu permainan skill play adalah bermain lilin (Fradianto, 2014). Lilin biasa disebut juga dengan plastisin atau playdought.

Plastisin atau playdought adalah lilin malam lembut yang mudah di bentuk sesuai keiginan dengan warna yang bervariasi dikarenakan teksturnya yang lembut. Terapi bermain dengan menggunakan lilin sangat tepat karna tidak membutuhkan energi yang besar untuk bermain, permainan ini juga dapat dilakukan diatas tempat tidur anak, sehingga tidak mengganggu dalam proses pemulihan dan penyembuhan kesehatan anak (Ngastiyah, 2005 dalam Fradianto, 2014). 
Pendapat ini juga didukung oleh penelitian yang dilakukan oleh Dayani, dkk (2015) tentang terapi bermain clay terhadap kecemasan pada anak usia prasekolah (3-6 tahun) yang mengalami hospitalisasi di RSUD Banjarbaru dimana penelitian ini menyebutkan permainan yang cocok diterapkan untuk anak usia prasekolah salah satunya adalah permainan membentuk (konstruksi) seperti clay. Terapi bermain dengan menggunakan jenis clay seperti plastisin atau playdough cocok diberikan pada anak yang sedang menjalani perawatan, karena tidak membutuhkan energi yang besar untuk bermain. Permainan ini juga dapat dilakukan di atas tempat tidur anak, sehingga tidak mengganggu dalam proses pemulihan kesehatan anak. Penelitian ini juga menunjukkan bahwa terdapat pengaruh pemberian clay terhadap penurunan kecemasan anak.

Namun menurut penelitian yang dilakukan oleh Muafifah (2013) tentang pengaruh clay therapy terhadap kecemasan akibat hospitalisasi pada pasien anak usia prasekolah di RSUD Banyumas menunjukkan bahwa tidak ada pengaruh clay therapy terhadap kecemasan akibat hospitalisasi pada pasien anak usia prasekolah di RSUD Banyumas.

RSUD Bangkinang merupakan satusatunya rumah sakit rujukan di kabupaten kampar dan sekitarnya. Berdasarkan data tahun 2016 di RSUD Bangkinang tercatat ada sebanyak 641 orang anak yang mengalami hospitalisasi, sedangkan data dari bulan Januari sampai Maret tahun 2017 menunjukkan ada 152 orang anak yang mengalami hospitalisasi di ruangan rawat inap anak RSUD Bangkinang, dengan jumlah anak prasekolah (3-6 tahun) yang mengalami hospitalisasi berjumlah 49 orang anak. Anak berumur 3 tahun berjumlah 10 orang anak, umur 4 tahun berjumlah 15 orang anak, umur 5 tahun berjumlah 13 orang anak dan 6 tahun berjumlah 11 orang anak. Hasil survey pendahuluan yang dilakukan peneliti, bahwa dari 4 orang anak usia prasekolah (3-6 tahun) yang menjalani hospitalisasi menunjukkan bahwa anak sering mengalami kecemasan pada saat dirawat yang ditandai dengan anak menjadi rewel, gelisah dan harus ditemani orang tua ketika menjalani perawatan ataupun mendapatkan tindakan medis.
Anak sering juga menangis ketika perawat memasuki ruangannya.

Berdasarkan hasil wawancara pada anak, orang tua anak dan perawat, penyebab kecemasan ini bervariasi mulai dari rasa cemas terhadap petugas kesehatan, serta tindakan seperti minum obat, jarum suntik dan lainnya. Selama ini tidak ada tindakan khusus atau terapi khusus yang diberikan kepada anak yang mengalami hospitalisasi di ruangan anak RSUD Bangkinang, anak hanya sebatas diberikan mainan oleh orang tuanya. Padahal jika kecemasan ini terus berlanjut, maka akan mempengaruhi proses penyembuhan anak. Hasil observasi dan wawancara juga menunjukkan bahwa selama ini pemberian terapi bermain plastisin (playdought) belum pernah dilakukan oleh perawat untuk mengurangi kecemasan pada anak yang mengalami hospitalisasi di ruang perawatan anak RSUD Bangkinang.

Dari permasalahan yang diuraikan diatas, maka peneliti tertarik untuk memberikan terapi bermain platisin (playdought) pada anak prasekolah yang mengalami hospitalisasi dengan melakukan penelitian yang berjudul "Pengaruh terapi bermain plastisin (playdought) terhadap kecemasan anak usia prasekolah (3-6 tahun) yang mengalami hospitalisasi di ruang perawatan anak RSUD Bangkinang tahun 2017”'

\section{Rumusan Masalah}

Berdasarkan uraian masalah pada latar belakang diatas, maka dirumuskan masalah penelitian yaitu : "Adakah pengaruh terapi bermain plastisin (playdought) terhadap kecemasan anak usia prasekolah (3-6 tahun) yang mengalami hospitalisasi di ruang perawatan anak RSUD Bangkinang Tahun 2017?”.

\section{Tujuan Penelitian \\ Tujuan Umum}

Untuk mengetahui pengaruh terapi bermain plastisin (playdought) terhadap kecemasan anak usia prasekolah (3-6 Tahun) yang mengalami hospitalisasi di ruang perawatan anak RSUD Bangkinang tahun 2017 


\section{Tujuan Khusus}

a. Untuk mengetahui tingkat kecemasan anak usia prasekolah (3-6 tahun) sebelum di berikan terapi bermain plastisin (playdought) di ruang perawatan anak RSUD Bangkinang tahun 2017.

b. Untuk mengetahui tingkat kecemasan anak usia prasekolah (3-6 tahun) sesudah di berikan terapi bermain plastisin (playdought) di ruang perawatan anak RSUD Bangkinang tahun 2017.

c. Untuk mengetahui adakah pengaruh terapi bermain plastisin (playdought) terhadap kecemasan anak usia prasekolah (3-6 Tahun) yang mengalami hospitalisasi di ruang perawatan anak RSUD Bangkinang tahun 2017

\section{METODE PENELITIAN \\ Desain Penelitian}

Jenis penelitian ini menggunakan rancangan eksperimen semu (quasi eksperimental) dengan rancangan. Metode quasi eksperimental (Nonequivalent pretest-posttest) merupakan suatu metode yang menggunakan hubungan sebab akibat yang melibatkan satu kelompok subyek. Penelitian ini dilakukan untuk mengetahui perbedaan tingkat kecemasan sebelum dan setelah diberikan perlakuan atau intervensi berupa terapi bermain plastisin (playdought).

\section{Lokasi dan Waktu Penelitian}

Penelitian ini di lakukan di ruangan perawatan anak Rumah Sakit Umum Daerah Bangkinang pada tanggal $22 \mathrm{Mei}$ s/d 06 Juni 2017.

\section{Populasi}

Populasi dalam penelitian ini adalah anak usia prasekolah (3-6 tahun) yang menjalani hospitalisasi di ruangan anak RSUD Bangkinang yang rata-rata berjumlah 15 orang setiap bulannya.

\section{Sampel.}

Sampel merupakan bagian dari populasi yang akan diteliti. Dalam penelitian keperawatan, Kriteria sampel meliputi Kriteria Inklusi dan Kriteria Ekslusi ( Hidayat, 2011).

a. Kriteria Inklusi penelitian ini adalah

1) Anak usia prasekolah (3-6 tahun) yang menjalani hospitalisasi di ruangan rawat inap anak RSUD Bangkinang.

2) Anak tidak mengalami gangguan pada eksremitas atas seperti fraktur atau luka bakar pada tangan

3) Anak kooperatif

b. Kriteria ekslusi

1) Anak dengan kondisi sangat lemah

2) Anak tiba-tiba mengalami kondisi gawat darurat

3) Orang tua atau keluarga tidak bersedia menjadi responden

Teknik pengambilan sampel yang digunakan dalam penelitian ini yaitu Nonprobability sampling dengan metode purposive sampling atau judgement sampling. Adapun jumlah sampel dalam penelitian ini adalah 15 orang.

\section{Alat Pengumpulan Data}

Alat pengumpulan data yang digunakan pada penelitian adalah kuesioner. Kuisioner yang digunakan untuk karakteristik responden terdiri dari :

1. Data karakteristik responden terdiri dari nama ibu dan anak, usia anak, pekerjaan ibu, jenis kelamin anak. Data ini diperoleh dengan mengajukan pertanyaan terbuka kepada orang tua pasien atau keluarga terdekat pasien.

2. Kecemasan Responden

Kecemasan responden diukur dengan menggunakan alat ukur (instrument) yang dikenal dengan nama T-MAS (Taylor Manifest anxiety Scale). Alat ukur ini berisi 24 butir pertanyaan observasi tingkat kecemasan anak usia prasekolah yang menggambarkan kecenderungan mengalami kecemasan. Reliabilitas dari TMAS ini telah di uji oleh Taylor dengan menggunakan testretest untuk tenggang waktu 3 minggu dan memperoleh indeks reliabilitas sebesar 0.89. TMAS juga sudah teruji validitas dan reliabilitasnya, berdasarkan korelasi Pearson di dapat skor validitas antara 0,60-0,88 dan memiliki nilai reliabilitas sebesar 0,78. (McDowell, 2006, dalam Paramita, 2013).

\section{Analisa Data}

Analisa yang digunakan adalah analisa univariat dan analisa bivariat. Dalam penelitian ini analisis bivariat digunakan untuk menganalisis perbedaaan kecemasan anak sebelum dan sesudah diberikan terapi bermain plastisin 
(playdought). sehingga dalam analisis ini dapat digunakan uji statistik uji T-test yaitu uji dua mean variabel.

\section{HASIL PENELITIAN}

Berdasarkan hasil penelitian yang telah dilakukan , maka diperoleh hasil sebagai berikut :

\section{Analisa Univariat}

1. Karakteristik Responden

Tabel 1:Distribusi Frekuensi Karakteristik Responden Usia Prasekolah (3-6 Tahun) Yang Mengalami Hospitalisasi Di Ruangan Perawatan Anak RSUD Bangkinang Tahun 2017

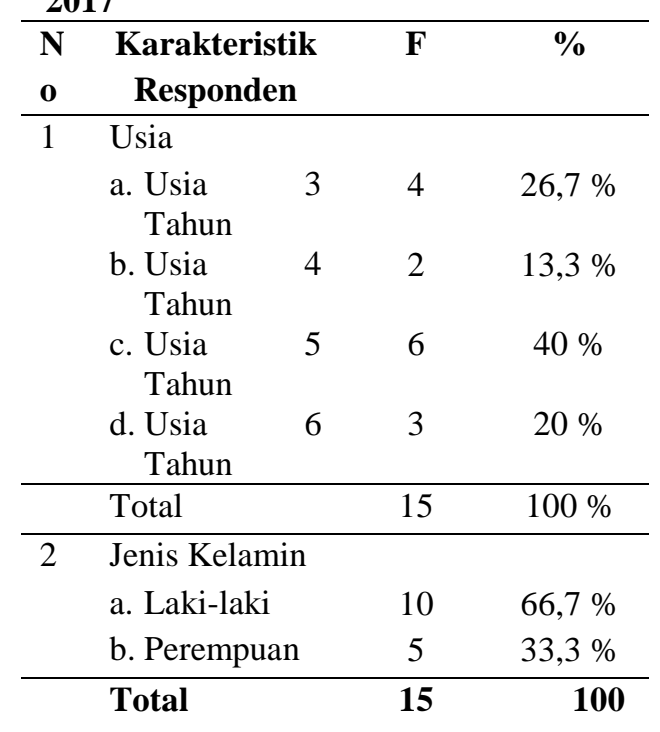

2. Kecemasan Responden

Tabel 4.2 : Distribusi Rata- Rata Tingkat Kecemasan Sebelum dan Setelah Diberikan Terapi Bermain Plastisin (Playdought)

\begin{tabular}{lcccc}
\hline Variabel & Mean & Median & SD & $\begin{array}{c}\text { Min- } \\
\text { Max }\end{array}$ \\
\hline $\begin{array}{l}\text { Tingkat } \\
\text { kecemasan }\end{array}$ & & & & \\
$\begin{array}{l}\text { Sebelum } \\
\text { terapi } \\
\text { bermain }\end{array}$ & 14,07 & 14,00 & 2,314 & $10-$ \\
plastisin & & & & 19 \\
$\begin{array}{l}\text { Setelah } \\
\text { terapi } \\
\text { bermain } \\
\text { plastisin }\end{array}$ & 9,60 & 10,00 & 2,293 & $6-13$ \\
\hline
\end{tabular}

\section{Analisa Bivariat}

Dalam penelitian ini analisis bivariat digunakan untuk menganalisis perbedaan tingkat kecemasan responden sebelum dan setelah di berikan terapi bermain plastisin (playdought). Dalam analisis ini peneliti menggunakan uji statistik uji $\mathrm{T}$ test atau Paired $\mathrm{T}$ Test yaitu uji dua mean dependen. Hasil perbandingan kecemasan responden sebelum dan setelah di berikan terapi bermain plastisin (playdought) peneliti sajikan dalam bentuk tabel 3 berikut ini:
Tabel 3 : Analisis Pengaruh Terapi Bermain Plastisin (Playdought) Terhadap Kecemasan Anak Prasekolah (3-6 Tahun) Yang Mengalami Hospitalisasi Di Ruang Perawatan Anak RSUD Bangkinang Tahun 2017

\begin{tabular}{llccccc}
\hline Variabel & $\begin{array}{l}\text { Pengu } \\
\text { kuran }\end{array}$ & Mean & SD & SE & Pv & N \\
$\begin{array}{l}\text { Tingkat } \\
\text { kecemasan }\end{array}$ & Sebelum & 14,07 & 2,31 & 0,59 & & \\
$\begin{array}{l}\text { Tingkat } \\
\text { kecemasan }\end{array}$ & Setelah & 9,60 & 2,29 & 0,59 & & 5 \\
\hline
\end{tabular}

Dari tabel 3 dapat dilihat bahwa rata-rata tingkat kecemasan responden sebelum diberikan intervensi berupa terapi bermain plastisin (playdought) adalah 14,07 dengan standar deviasi 2,314. Sedangkan setelah diberikan terapi bermain plastisin (playdought) rata-rata tingkat kecemasan responden adalah 9.60 dengan standar deviasi 2, 293.

Hasil uji statistik didapatkan nilai $\mathrm{P}$ value adalah 0,00. Apabila dibandingkan dengan nilai $\alpha$ maka nilai $\mathrm{P}=0,00<\alpha=$ 0,05 yang menunjukkan bahwa ada perbedaan yang signifikan antara tingkat kecemasan sebelum dan setelah diberikan intervensi berupa terapi bermain plastisin (playdought).

\section{PEMBAHASAN}

\section{A. Karakteristik Responden}

1. Usia

Berdasarkan hasil penelitian menujukkan bahwa sebagian besar responden berusia 5 tahun yang berjumlah sebanyak 6 responden $(40 \%)$, usia 3 tahun yang berjumlah sebanyak 4 responden $(26,7 \%)$, Usia 6 tahun yang berjumlah sebanyak 3 respoden (20\%) serta usia 4 tahun yang berjumlah 2 responden $(13,3 \%)$. Supartini (2004) menjelaskan bahwa anak usia prasekolah merupakan anak yang berada pada rentang usia 3-6 tahun.

Rasa takut pada anak usia 3-6 tahun umumnya terjadi seperti takut kegelapan, ditinggal sendiri terutama pada saat menjelang tidur, takut terhadap tindakan medis dan petugas kesehatan, seringkali anak usia prasekolah menganggap bahwa hospitalisasi adalah sebagai hukuman dan pemisahan dari orang tua dan hal inilah yang menyebabkan kecemasan pada anak yang menjalani hospitalisasi.

Berdasarkan perhitungan dari perubahan skor kecemasan dapat terlihat bahwa pada anak usia 3 dan 4 tahun lebih banyak 
mengalami peningkatan kecemasan dibandingkan usia 5 dan 6 tahun hal ini sesuai dengan pendapat Wong (2009) yang menyatakan bahwa semakin muda usia anak semakin sulit bagi anak untuk beradaptasi dengan pengalaman di rawat dirumah sakit.

Dari teori dan hasil penelitian diatas maka peneliti berpendapat bahwa semakin muda usia anak maka akan semakin tinggi tingkat kecemasan akibat hospitalisasi yang dialaminya. Hal ini berkaitan dengan semakin muda usia anak maka akan semakin sulit baginya untuk menyesuaikan diri dengan lingkungan rumah sakit yang dianggap asing serta menakutkan bagi seorang anak.

\section{Jenis Kelamin}

Dari hasil penelitian, karakteristik responden menunjukkan bahwa sebagian besar responden terdiri dari laki-laki berjumlah sebanyak 10 responden $(66,7 \%)$ dan perempuan yang berjumlah sebanyak 5 responden $(33,3 \%)$. Hal ini dikarenakan jumlah pasien anak prasekolah yang dirawat di ruang perawatan anak RSUD Bangkinang lebih banyak berjenis kelamin laki-laki dibandingkan perempuan. Hal ini di dukung oleh pendapat Hurlock (2002) dalam Muafifah (2013) yang menyatakan jenis kelamin anak akan mempengaruhi aktivitas bermain anak. Anak laki-laki lebih banyak melakukan permainan yang menghabiskan energi dibandingkan anak perempuan, sehingga anak laki-laki lebih beresiko terkena penyakit atau cidera.

Berdasarkan teori dan hasil penelitian, maka peneliti berpendapat bahwa anak laki- laki lebih mudah terserang penyakit dikarenakan anak laki-laki lebih banyak melakukan pemainan yang menghabiskan energi dari pada anak perempuan, sehingga menyebabkan anak laki-laki lebih sering mengalami hospitalisasi dibandingkan anak perempuan.

\section{Kecemasan Responden}

Dari hasil penelitian, dapat diketahui bahwa rata-rata kecemasan responden sebelum diberikan intervensi berupa terapi bermain plastisin (playdought) yaitu 14,07, sedangkan setelah diberikan intervensi berupa terapi bermain plastisin (playdought) rata-rata kecemasan responden yaitu 9,60.
Kecemasan yang dialami anak yang menjalani hospitalisasi di ruang perawatan anak RSUD Bangkinang di sebabkan oleh rasa takut terhadap petugas kesehatan, tindakan medis, cemas karena berada pada lingkungan baru yang asing bagi anak, serta rasa cemas akibat berpisah dari teman-teman dan keluarganya. Hal ini sesuai dengan pendapat Alfiyanti (2007) dalam Dayani (2015) yang mengatakan bahwa kecemasan pada anak usia prasekolah disebabkan karena kecemasan terjadinya perlukaan pada bagian tubuh, serta semua prosedur dan tindakan medis yang dialami.

\section{B. Pengaruh Pemberian Terapi Bermain Plastisin (Playdought) Terhadap Perubahan Kecemasan Anak Usia Prasekolah (3-6 Tahun) Yang Mengalami Hospitalisasi Di Ruangan Perawatan Anak RSUD Bangkinang}

Berdasarkan hasil penelitian diketahui bahwa terjadi penurunan tingkat kecemasan pada anak usia prasekolah (36 tahun) yang mengalami hospitalisasi di ruangan perawatan anak RSUD Bangkinang setelah di berikan intervensi berupa terapi bermain plastisin (playdought). Dari hasil penelitian didapatkan bahwa rata-rata tingkat kecemasan responden sebelum diberikan intervensi berupa terapi bermain plastisin (playdought) adalah 14,07 Sedangkan setelah diberikan terapi bermain plastisin (playdought) rata-rata tingkat kecemasan responden adalah 9.60 sehingga perbedaan tingkat kecemasan responden sebelum dan setelah pemberian terapi bermain plastisin (playdought) adalah sebesar 4,467 .

Hasil uji statistik dengan menggunakan uji paired sample $T$ - test menunjukkan nilai $\mathrm{p}=0,00<0,05$ yang berarti ada pengaruh yang signifikan pemberian terapi bermain plastisin (Playdought) terhadap kecemasan anak usia prasekolah (3-6 tahun) yang mengalami hospitalisasi di ruang perawatan anak RSUD Bangkinang.

Terapi bermain plastisin (playdought) dapat menurunkan kecemasan anak usia prasekolah (3-6 tahun) yang menjalani hospitalisasi di ruang perawatan anak RSUD Bangkinang, karena terapi 
bermain platisin (playdought) dapat membantu anak untuk mengekspresikan perasaannya melalui kegiatan bermain sehingga anak merasa lebih nyaman. Hal ini didukung oleh pendapat Sujatmiko (2013) dalam Dayani (2015) yang menyatakan bahwa salah satu cara yang digunakan untuk mengurangi kecemasan pada anak adalah dengan terapi bermain. Bermain merupakan suatu aktivitas dimana anak dapat melakukan atau mempratikkan keterampilan, ekspresi serta pemikiran ( Hidayat, 2005).

Dalam penelitian ini terapi bermain platisin (playdought) diberikan sebanyak 1 kali selama 10 sampai 15 menit, dimana pemberian terapi ini mampu menurunkan rata-rata tingkat kecemasan anak sebesar 4,46, sedangkan pada penelitian yang dilakukan Dayani (2015) pemberian terapi bermain Clay di lakukan sebanyak 2 kali selama 2 hari ( 1 hari 1 kali pemberian terapi) dengan waktu 20 menit dan dapat menurunkan rata- rata tingkat kecemasan anak sebesar 5,30. Kondisi ini memberikan gambaran bahwa jika terapi bermain plastisin (playdought) dilakukan lebih sering dan dengan waktu yang lebih lama maka akan menyebabkan penurunan tingkat kecemasan anak lebih maksimal.

Supartini (2004) menyatakan anak yang mengalami hospitalisasi akan mengalami kejadian yang sangat traumatik dan penuh dengan stress. Penyebab stress pada anak diantaranya adalah lingkungan rumah sakit itu sendiri seperti bangunan rumah sakit, ruang rawat, alat-alat medis, pakain putih petugas dan lingkungan sosial. Kondisi ini merupakan sumber stress (stressor) yang dapat mempengaruhi psikologis anak. Beberapa tahun ini clay termasuk plastisin sering digunakan untuk bermain anak-anak dalam kegiatan terapi bermain, terapi ini selain untuk menurunkan kecemasan juga digunakan oleh terapis sebagai sarana untuk meningkatkan hubungan terapeutik.

Yusuf (2002) dalam Muafifah (2013) menyatakan salah satu permainan yang cocok untuk anak usia prasekolah adalahpermainan membentuk (kontruksi) dan clay merupakan salah satu permainan membentuk. Sehingga plastisin (playdought) yang merupakan salah satu jenis clay dapat digunakan sebagai terapi bermain yang efektif di berikan kepada anak usia prasekolah yang menjalani hospitalisasi untuk menurunkan kecemasan akibat hospitalisasi. Hal ini juga di dukung oleh penelitian Dayani, dkk (2015) yang menyatakan bahwasanya terdapat pengaruh terapi bermain clay terhadap kecemasan anak usia prasekolah (3-6 tahun) yang menjalani hospitalisasi, Penelitian ini juga sejalan dengan penelitian Ikbal (2014) yang juga menyatakan hal yang sama, bahwa terdapat pengaruh terapi bermain lilin terhadap penurunan tingkat kecemasan anak usia prasekolah yang mengalami hospitalisasi.

\section{Analisis Perbandingan Perbedaan Penelitian Sebelumnya Dengan Penelitian Yang Dilakukan Peneliti Saat Ini}

Dayani (2015) melakukan penelitian yang berjudul terapi bermain clay terhadap kecemasan anak usia prasekolah (3-6 tahun) yang menjalani hospitalisasi di RSUD Banjarbaru. Penelitian ini bersifat quasi eksperimental dengan rancangan penelitian pretest-posttest non equivalent control group design. Pengambilan sampel sebanyak 26 orang anak usia prasekolah yang terbagi atas 13 orang anak kelompok kontrol dan 13 orang anak kelompok eksperimen dengan menggunakan teknik accidental sampling. Pada penelitian ini pemberian terapi bermain Clay di lakukan sebanyak 2 kali selama 2 hari (1 hari 1 kali pemberian terapi) dengan waktu 20 menit dengan jumlah sampel sebanyak 26 orang, 13 orang anak kelompok kontrol dan 13 orang anak kelompok eksperimen. Kesimpulan penelitian ini adalah bahwa terdapat pengaruh terapi bermain clay terhadap kecemasan pada anak usia prasekolah (3-6 tahun) yang menjalani hospitalisasi di RSUD Banjarbaru dan dapat menurunkan rata- rata tingkat kecemasan anak sebesar 5,30.

Penelitian yang dilakukan oleh Ikbal (2014) yang berjudul pengaruh terapi bermain lilin terhadap penurunan tingkat kecemasan pada anak usia prasekolah yang mengalami hospitalisasi di RSUD dr. Soedarso Pontianak. Penelitian ini dilakukan untuk mengetahui ada tidaknya pengaruh terapi bermain lilin terhadap penurunan tingkat kecemasan pada anak usia prasekolah. Jenis penelitian ini 
menggunakan pre-eksperimen dengan one group pre-post test design. jumlah sampel 20 anak yang dilakukan dengan teknik pengambilan sampel purposive sampling. Pada penelitian ini terapi bermain lilin diberikan sebanyak 2 kali dalam sehari dengan waktu 20-25 menit. Kesimpulan penelitian ini ada pengaruh terapi bermain lilin terhadap penurunan tingkat kecemasan pada anak usia prasekolah di Ruang Anak RSUD dr. Soedarso Pontianak dengan rata-rata penurunan kecemasan sebesar 6,45 .

Muafifah (2013) melakukan penelitian yang berjudul pengaruh clay therapy terhadap kecemasan akibat hospitalisasi pada pasien anak usia prasekolah di RSUD Banyumas. Penelitian ini menggunakan desain pre eksperimen dengan pendekatan pre-post test one group design, dengan teknik pengambilan sampel menggunakan consecutive sampling dan jumlah sampel sebanyak 18 orang anak usia prasekolah. Dalam penelitian ini terapi bermain diberikan selama 3 hari (1 hari 1 kali pemberian terapi bermain). Kesimpulan penelitian ini adalah tidak ada pengaruh clay therapy terhadap kecemasan anak yang dirawat di RSUD Banyumas. Hal ini dikarenakan anak yang tidak kooperatif serta sulit untuk diajak berkomunikasi.

Pada penelitian yang telah dilakukan peneliti, terapi bermain platisin (playdought) diberikan sebanyak 1 kali selama 10 sampai 15 menit dengan sampel berjumlah 15 orang tanpa adanya kelompok kontrol (pre eksperimen pretest and post test one group design) dengan teknik pengambilan sampel Nonprobability sampling menggunakan metode purposive sampling atau judgement sampling. Kesimpulan penelitian ini adalah terdapat pengaruh terapi bermain plastisin (playdought) terhadap kecemasan anak usia prasekolah dengan rata-rata penurunan kecemasan sebesar 4,46. Jadi dari analisis perbandingan ini dapat peneliti simpulkan bahwa walaupun terapi bermain yang diberikan sama-sama menggunakan media bermain berupa clay atau plastisin ( playdouhgt) tetapi kelebihan penelitian ini adalah penelitian ini hanya diberikan dalam waktu yang singkat sehingga tidak mengganggu waktu istrirahat dan proses penyembuhan anak, pada penelitian ini juga tidak memerlukan tempat khusus untuk bermain sehingga bisa dilakukan dengan mudah oleh perawat kepada anak yang mengalami hospitalisasi.

\section{KESIMPULAN DAN SARAN Kesimpulan}

Berdasarkan hasil penelitian dan pembahasan diuraikan diatas, maka ditarik kesimpulan sebagai berikut :

1. Rata- rata kecemasan anak sebelum diberikan terapi bermain plastisin (playdought) adalah 14,07.

2. Rata- rata kecemasan anak setelah diberikan terapi bermain plastisin (playdought) adalah adalah 4,47.

3. Ada pengaruh pemberian terapi bermain plastisin (playdought) terhadap perubahan kecemasan pada anak usia prasekolah (3-6 tahun) yang mengalami hospitalisasi di ruangan perawatan anak RSUD Bangkinang, dibuktikan dengan uji T-test dependen dengan $\mathrm{P}$ Value $0,00(\mathrm{P}<0.05)$

\section{Saran}

\section{Teoritis}

Diharapkan bagi penelitian selanjutnya dapat mengembangkan penelitian tentang terapi bermain yang berbeda seperti terapi bermain origami yang bisa diberikan kepada anak untuk mengurangi tingkat kecemasan akibat hospitalisasi.

\section{Praktis}

Diharapkan kepada petugas kesehatan khususnya kepada petugas kesehatan di RSUD Bangkinang agar mempertimbangkan terapi bermain plastisin (playdought) sebagai salah satu terapi bermain yang bisa diterapkan untuk mengurangi tingkat kecemasan akibat hospitalisasi pada anak usia prasekolah.

\section{DAFTAR PUSTAKA}

Ade. (2011). Asuhan keperawatan jiwa. Yogyakarta: Nuha Medika.

Apriany, D. (2013). Hubungan antara hospitalisasi anak dengan tingkat kecemasan orang tua. Jakarta: Jurnal Keperawatan Soedirman.

Dayani, Noer Ella, dkk. (2015). Terapi Bermain Clay Terhadap Kecemasan pada Anak Usia Prasekolah yang Menjalani Hospitalisasi di RSUD Banjarbaru. Skripsi. Tidak diterbitkan; Program Studi Ilmu Keperawatan Fakultas Kedokteran Universitas Lambung Mangkurat. 
Debbi, (2013). Hubungan Penerapan Atraumatic Care Dengan Kecemasan Anak Prasekolah Saat Proses Hospitalisasi. Skripsi. Tidak diterbitkan: Universitas jember.

Fradianto. (2014). Pengaruh terapi bermain lilin terhadap penurunan tingkat kecemasan pada anak usia prasekolah. di RSUD DR. Soedarso pontianak Skripsi. Tidak diterbitkan: Pontianak.

Fithriyatul, dkk. (2016). Kerangka Teori dan Kerangka Konsep. Tesis. Tidak diterbitkan: Universitas Indonesia.

Harjaningrum, (2007). Peran Orang Tua dan Praktisi Dalam Membantu Tumbuh Kembang Anak Berbakat Melalui Pemahaman Teori dan Trend Pendidikan. jakarta: Prenada media.

Hawari, dadang. (2004). Cemas dan depresi. Jakarta: FKUI

Hidayat, A. A. (2005). Pengantar Ilmu Keperawatan. Jakarta: Salemba Medika.

Hidayat, A. A. (2011). Metode Penelitian Keperawatan dan Teknik Analisis Data. jakarta; salemba medika.

Kyle,Terry dan Susan Carman.(2014). buku ajar keperawatan pediatric dialih bahasakan oleh devi yulianti. Jakarta: EGC.

Liswaryana. (2016). Faktor-Faktor yang Berhubungan Dengan Kecemasan Anak Prasekolah yang Mengalami Hospitalisasi Diruangan Anak Bangkinang Tahun 2016. Skripsi. Tidak diterbitkan; Program Studi SI Keperawatan STIKes Tuanku Tambusai Riau.

Muscari, M. E. (2005). Panduan Belajar : Keperawatan Pediatrik. Jakarta: EGC.

Ngastiyah. (2005).Perawatan Anak Sakit Edisi 2. Jakarta: EGC.

Notoatmodjo S.( 2010). Metodologi Penelitian Kesehatan. Jakarta: Rineka Cipta.

Nursalam, (2005). Asuhan Keperawatan Bayi dan Anak Edisi 1. Jakarta : Salemba Medika.

Nursalam. (2011). Konsep dan Penerapan Metodologi Penelitian Ilmu Keperawatan. Jakarta: Salemba medika.

Sari, Silvia Ratna .(2016).Pengaruh Bibioterapi Dengan Buku Cerita Bergambar Terhadap Tingkat Kecemasan Efek Hospitalisasi Pada Anak Prasekolah Di Ruangan Anak
Di RSUD Bangkinang tahun 2016. Skripsi. Tidak diterbitkan; Program Studi SI Keperawatan STIKes Tuanku Tambusai Riau.

Stuart dan Sundeen (2002). Buku Saku Keperawatan Edisi 3.Jakarta: EGC.

Sukarmin. (2009). Asuhan Keperawatan Pada Anak. Yogyakarta: Graha Ilmu.

Supartini, Y. (2005). Buku Ajar Konsep dasar Keperawatan Anak. Jakarta: EGC.

Survei Kesehatan Nasional (SUSENAS). (2010). Jumlah anak usia prasekolah di indonesia. 2015.

Tedjasaputra, M.S. (2010). Bermain Mainan dan Permainan. Jakarta: Grasindo.

UNICEF.Fund.(online),(http://www.unice f.org/dprk/unicef-factsheet2013, diakses 18Februari 2014.

Wong, Donna L, dkk. (2009). Buku Ajar Keperawatan Pediatri volume 2. Jakarta :EGC 